\title{
SOARING IN THE SKY; EFFORTS BY UNITED ARAB EMIRATES IN AIR AND SPACE ACTIVITIES
}

\author{
SARATH RAJ N. $\mathbf{S}^{\mathbf{1}} \boldsymbol{\&}$ GEETANJALI RAMESH CHANDRA ${ }^{\mathbf{2}}$ \\ ${ }^{1}$ Faculty Member of Aerospace Engineering, Amity University, Dubai, United Arab Emirates \\ ${ }^{2}$ Faculty Member of Law, Amity University, Dubai, United Arab Emirates
}

\begin{abstract}
“The Sky's The Limit For Our Ambitions But That Requires A Team Determined Enough To Attain This”

His Highness Shaikh Khalifa Bin Zayed Al Nahyan

Aviation is one of the quickest and steadily developing ventures around the globe. As indicated by the Air traveler Forecasts Global Report of IATA, October 2015, the travelers number is developing by $5.4 \%$ every year in United Arab Emirates. The flying segment is critical to the UAE's economy, as it contributes more than $15 \%$ or US\$ 46 billion to the nation's GDP, and is relied upon to increment to $38 \%$ or US\$ 53 billion by 2020. Dubai's prosperity zenith lies into clear vision, persistent planning, and worldwide synergistic execution. UAE's aviation precinct is thriving to be a world pioneer in the business, the country has thought of part of activity like building up GCAA, passing Federal Law Number 4 and 20 identified with Civil Aviation and Aviation Authority law, however, it has their own difficulties like purview issue, authorizing prerequisites, state of carriage, wellbeing and security. Moving to space area in 2014, the UAE made the fundamental stride towards turning into a space part pioneer, with the foundation of the UAE Space Agency marked three UN settlements identified with space law. UAE keeps on upgrading and build up its administrative system to pull in outside venture and PPP show outline work in a joint effort with Boeing, Airbus, NASA, and Thuraya to name few. UAE is the signatory for a few different treaties and convention to conquer the difficulties confronting in the space area like Outer Space Treaty, Treaty on Principles Governing the Activities of States in the Exploration and Use of Outer Space, including the Moon and Other Celestial Bodies, Liability Convention, Convention on International Liability for Damage Caused by Space Objects, Registration Convention, Convention on Registration of Objects Launched into Outer Space.UAE Government has been proposing UAE National Space Policy, UAE Space Law and Regulations, UAE Space Strategy (10 years design) for the fruitful voyage in the space division. The paper will concentrate on lawful issue relating to different endeavors taken by United Arab Emirates for air and space activities.

KEYWORDS: Aviation, Space, Aviation Law, Treaties, Aviation Policy, Civil Aviation Authority, GCAA, Space Law, UAE Space Strategy \& National Space Agency
\end{abstract}

Received: Jun 23, 2017; Accepted: Jul 10, 2017; Published: Jul 21, 2017; Paper Id: IJBMRAUG20173

\section{INTRODUCTION}

The UAE's massive investments in infrastructure and logistics have turned it into a regional and global trade, tourism and business hub. Dubai's ports, air terminals, land-sea-air transport organizations have changed it into an Aerotropolis, a city whose actions are progressively connected to its airplane terminals. Unified transport frameworks and productive coordination encourages exchange merchandise and services and empower versatility and universal connectedness. The aviation industry is a transnational one, creating billions of dollars in income, utilizing a great many individuals, and including numerous nations around the world. The present worldwide 
economy, in any case, has started a constant verbal confrontation about the advancement of air law and keeps on setting awesome weight to grow new thoughts that may effectively affect civil aviation. There is a developing need to manage space activities as more nations set up and grow space programs. The idea of space exercises has changed from staterepresented into private endeavors that have made a few difficulties to space law also. Global as well as national activities and laws should adapt to these current advancements and fill any administrative gaps. United Arab Emirates (UAE) is one of the main nations in air and space industry, as it is home to one of the biggest airports globally, for example, Etihad Airways, Emirates Airline, and Air Arabia ${ }^{1}$. Moreover, the UAE space program prompted fruitful dispatch of a few satellites and numerous more to come. The global aviation industry keeps on developing quickly, however reliable and vigorous productivity is tricky. Measured by income, the industry has multiplied over the previous decade, as indicated by International Air Transport Association (IATA) ${ }^{2}$

The fast development of aviation in devolping nations, for example, Latin America and particularly Asia, is considering UAE as a focal point. The Middle East carriers are highly dependent on connecting traffic, because their home markets are limited by the smaller population of their region. Because of the geographical location of UAE, the region could connect the long haul market within eight flying hours. ${ }^{3}$ According to Gaith Al Gaith, flydubai's CEO "The UAE's aviation industry has grown exponentially over the past two decades. The geographical location of the country at the crossroads of East and West has aided its passenger appeal, as it is an excellent stopover destination to break long flights between continents." ${ }^{4}$ In 2015, UAE being recognized by International Civil Aviation OrganizationICAO for having the world's safest aviation industry, Dubai International airport also recognized as world's leading airport for global movements. ${ }^{5}$

Table 1

\begin{tabular}{|l|l|}
\hline \multicolumn{2}{|c|}{ UAE MILESTONE IN AVIATION INDUSTRY } \\
\hline YEAR & \multicolumn{1}{|c|}{ ACHIEVEMENTS } \\
\hline 1929 & Imperial Airways approach Sharjah to build an airport. \\
\hline 1932 & Al Mahatta Sharjah Airport is opened for operation. \\
\hline 1940 & The Royal Air force use Al Mahatta as a base during the $2^{\text {nd }}$ World War \\
\hline 1959 & Establishment of Dubai International Airport \\
\hline 1960 & Dubai Airport was opened handling aircraft size of a DC-3 \\
\hline 1965 & Dubai opens its first asphalt runway \\
\hline 1968 & Abu Dhabi Airport opens named "Al Bateen Airport" \\
\hline 1976 & Ras Al Khaimah airport was inaugurated \\
\hline 1977 & Sharjah International opens and Al Mahatta closes, eventually falling into disrepair \\
\hline 1981 & Abu Dhabi International Airport started operation \\
\hline 1985 & Emirates airline was launched. \\
\hline 1987 & Fujairah International Airport opens \\
\hline 1994 & Al Ain International opens \\
\hline 1996 & General Civil Aviation Authority by Federal Cabinet Decree (Law 4) \\
\hline 1998 & Al Mahatta Museum opens at the original airport after being restored \\
\hline
\end{tabular}

\footnotetext{
1 “Mohammed bin Rashid Space Centre showcases “ http://www.mediaoffice.ae/en/mediacenter/news/5/11/2016/mbrsc.aspx

${ }^{2}$ Clayton Edward ,Hilz Andreas, "2015 Aviation Trends”, http://www.strategyand.pwc.com/trends/2015-aviationtrends

${ }^{3}$ Clayton Edward ,Hilz Andreas, “2015 Aviation Trends”, http://www.strategyand.pwc.com/trends/2015-aviation- trends

${ }^{4}$ Jain Shweta, “UAE aviation: A story of takeoffs and landings”, http://gulfnews.com/business/aviation/uae-aviation-a-story-oftakeoffs-and-landings-1.925143, November $7^{\text {th }} 2011$

5 "UAE aviation industry sees robust growth", http://gulftoday.ae/portal/a5d9bba1-d58f-4494-89b5-2a26bf26315a.aspx,July 20 th 2015
} 


\begin{tabular}{|l|l|}
\hline 2003 & Air Arabia launched \\
\hline 2003 & Etihad, designated as the 'national airline of the UAE', was formally launched \\
\hline 2006 & RAK Airways was established \\
\hline 2008 & Flydubai was established \\
\hline 2008 & Emirates Terminal 3 at Dubai International Airport started its operation \\
\hline 2009 & $\begin{array}{l}\text { After Air Arabia, Flydubai launched as UAE's second low-cost carrier in regional aviation sector with } \\
\text { the unveiling of its first Boeing 737-800 }\end{array}$ \\
\hline 2010 & Dubai World Central (DWC) - Al Maktoum International Airport for cargo operations started \\
\hline 2011 & Air Arabia bags best low cost International Airline Award \& Etihad named 'Best International Airline'. \\
\hline 2012 & Etihad Airways operates first biofuel powered delivery flight \\
\hline 2013 & Concourse A testimony to UAE's successful aviation policy \\
\hline 2014 & GCAA launches 'SAMAE' mobile app \& GCAA inks final Air Services Agreement with India \\
\hline 2015 & UAE marks 83 years of aviation progress \\
\hline 2016 & $\begin{array}{l}\text { UAE wins seat at ICAO Council elections \& UAE Representative elected as First Vice President of } \\
\text { ICAO Council \& passenger traffic tops seven million at DXB Airport }\end{array}$ \\
\hline
\end{tabular}

Source: compiled by authors through,http://gulfnews.com/business/aviation/uae-aviation-a-story-of-takeoffs-andlandings-1.925143\& http://www.uaeinteract.com/news/default3.asp?page $=33 \& I D=27$

The year 2016 evidenced a shocking year for aviation industry of UAE, with the decease of two major planes of Emirates and Fly Dubai as well as a numerous aviation incidents as per the Air Accident Investigation department of General Civil Aviation Authority (GCAA). ${ }^{6}$. Aviation safety affects everybody from governments, passengers, industry, freight companies and academic community. The UAE's principal concern on the aviation legislation can be established in the Federal Law 20 of 1991 (the civil Aviation Law), the Federal law 4 of 1996 (the Aviation Authority Law) and the Federal law 20 of 2001. Ranging various scopes of law, the civil aviation law applies to operating or registered in UAE, air traffic controls communication and civil airports. The Aviation Authority law establishes the GCAA to oversee compliance with the civil aviation law to ensure continuous development and enhancement to the airspace infrastructure to ensure a safe and sustainable civil aviation sector ${ }^{7}$. The reason for the UAE airspace strategy will be with make effective, efficient, safe, secure, receptive and adaptable surroundings inside, which requests for entry with national airspace don't set a demand ahead sensible development in the aviation sector of the economy ${ }^{8}$.

\section{UAE GOVERNMENT INITIATIVES FOR AIR ACTIVITIES}

\section{UAE Civil Aviation Day}

At present, UAE is renowned for its international excellence in all aspects of aviation. Every year, the GCAA, with the support of the Federal Cabinet, marked the $5^{\text {th }}$ October as UAE Civil Aviation Day from 2014 to celebrate and recognize the extraordinary dedication of UAE in developing the aviation sector ${ }^{9}$.

\section{National Aviation Security Program}

GCAA carried out National Aviation Security Program for the industry, in order to enhance the standards and procedures for security of all cargo transported by air, GCAA has developed and implemented ${ }^{10}$

\footnotetext{
${ }^{6}$ https://www.gcaa.gov.ae/en/departments/airaccidentinvestigation/pages/default.aspx

${ }^{7}$ https://www.gcaa.ae/cms_data/Files/Federal\%20Act\%20no\%2020\%20for\%201991-\%20Civil\%20Aviation\%20Law\%20Eng.pdf

${ }^{8}$ GM 04 UAE ATM Strategic Plan Version 1.0 issue 2014 (2).pdf

${ }^{9}$ GCAA, General Civil Aviation Authorit, 2014. UAE CIVIL AVIATION DAY. AJWAA, Issue 1, 12,13.

${ }^{10}$ Regulations Specialist, nyadav, 2015. UAE, GCAA CAR - PART VII AVIATION SECURITY REGULATIONS. CAR - PART VII AVIATION SECURITY REGULATIONS, Third Edition, October 2015, 3-1
} 


\section{National Screener Certification Program}

GCAA additionally displayed a draft correction to the system for the transportation of perilous merchandise via air, which was affirmed by ICAO and actualized by the states. In accordance with International Association of Air Transport (IATA) rules, GCAA completed a review to enhance the administrations and methodology for travelers with unique needs or requiring medicinal consideration ${ }^{11}$.

\section{State Safety Program (Ssp)}

The State Safety Program (SSP) is a moderately new idea and introduction of this concept in UAE presents challenges on all levels i.e. framework, process, and individuals. GCAA, similar to some other civil aviation authority (CAA), underpins its Safety Management Systems (SMS) through compelling oversight exercises, rulemaking and strategy improvement. However, rather than responding to the latest mishap, SSP rulemaking depends on the thorough examinations of the State's aviation framework. ${ }^{12}$

\section{Development and Implementation of Rosi (Reporting of Safety Issues)}

The improvement and usage of ROSI (Reporting of Safety Issues) and the mechanization of an oversight framework through Q-pulse are two of the framework upgrades accomplished amid the 2007-2010 period. The usage of ROSI has brought about 470 reports, since the dispatch of this venture in January 2010. GCAA has likewise effectively executed SAFA (Safety Audit of Foreign Airlines) and Q-Pulse in Flight Operations and Airworthiness. ${ }^{13}$

\section{Air Operator Certificate}

The GCAA has redesigned the particulars and prerequisites to get the Air Operator Certificate in accordance with the measures set by ICAO, in this way, getting to be distinctly one of the first establishments to execute this activity. ${ }^{14}$

\section{Search And Rescue Conference (Sar)}

The first international search and rescue conference (SAR) in the history of ICAO was held in Abu Dhabi, hosted and organized by the UAE General Civil Aviation Authority (GCAA) and attended by the President of the ICAO, council members and more than 250 delegates from around the world. ${ }^{15}$

\section{Online Data Interchange (Oldi)}

To enhance the administrations to its clients, GCAA included full remain self-contained Online Data Interchange (OLDI) capacity and acquaintance of OLDI associations with significant local airplane terminals and proficient adjoining centers.

Initiation of Arrival Metering and Sequencing (AMAN) for UAE airport terminals and a mechanized Aeronautical Information Management (AIM) framework with electronic Aeronautical Information Publication (AIP) and Notice to

\footnotetext{
${ }^{11}$ https://www.gcaa.gov.ae/en/Departments/ASI/Pages/AviationSafetySecurity.aspx.

${ }^{12}$ https://www.gcaa.gov.ae/en/ePublication/Pages/uaessp.aspx

${ }^{13}$ https://www.gcaa.gov.ae/en/rosi/pages/details.aspx?_Lst=GCAA_Welcome:Body

${ }^{14}$ https://www.gcaa.gov.ae/en/epublication/admin/Publication\%20History/Civil\%20Aviation\%20Advisory\%20Publication\%20(CAAP )/CAAP\%208\%20-\%20AIR\%20OPERATERS\%20CERITIFICATE\%20(AOC)\%20ISSUE\%2002\%20-\%20REV\%2000.pdf

${ }^{15}$ https://www.gcaa.gov.ae/en/pages/events.aspx?EventID=10
} 
Airmen (NOTAM) conveyance and database are major GCAA activities under OLDI. ${ }^{16}$

\section{Communication Channels}

For enhancing correspondence norms with clients, GCAA effectively actualized four correspondence channels, e.g. Twitter, Call Center, and Interactive Voice Response (IVR). Later, GCAA introduced online chats, Enquiry Service, Instagram, Face book, YouTube, Blogs, forums, SMS Enquiry, Service Tracking to support the communication with their clients. $^{17}$

\section{Optimization of Air Space Capacity}

The UAE has an aggregate of 120,000 square kilometers of airspace, with 35 universal air passageways. Today, more than 50 percent of UAE airspace is embraced of airborne rejection zones confined to military utilize. To make up for this shortage and the fast development of aircraft schedules in the UAE airspace, the GCAA has vigorously put resources into reception of new advancements to advance utilization of accessible airspace limit including ${ }^{18}$ :

- A best in class air traffic control center, the Sheik Zayed Center, was propelled in 2009.

- $\quad$ RNAV 1, a novel area navigation system, was espoused.

\section{Air Transport Bilateral Agreement}

Till date, 51 Open Skies agreements were established by the UAE, through several prospects for development between different nations around the world. ${ }^{19}$

\section{Benchmarking}

A benchmarking activity was executed by GCAA to get key lessons from nations, with a developed aviation framework. The benchmark concept ensued certain doctrine that steered the composition of the GCAA Strategic Plan. The benchmark practice concentrated on the following sector ${ }^{20}$ :

- Institutional set-up and administrative framework

- CAA administration

- Operating model and Organization

- Financial

\section{The Atm Community}

International Civil Aviation Organization (ICAO) defines Air Traffic Management (ATM) as the "dynamic, integrated management of air traffic and airspace — safely, economically and efficiently — through the provision of facilities and seamless services in collaboration with all parties" ${ }^{21}$. ATM Community in the UAE is embodied by the

\footnotetext{
${ }^{16}$ http://www.icao.int/RO_MID/Documents/2014/AIDC-OLDI\%20Seminar/Presentation1-OLDI\%20Experience\%20Sharing\%20\%20UAE.pdf

${ }^{17}$ https://www.gcaa.gov.ae/en/lists/gcaa\%20communication\%20channels\%20survey/newform.aspx?Source=/en/Pages/sThankYou .aspx

${ }^{18}$ https://www.mcgill.ca/iasl/files/iasl/Session_5_Karam.pdf

${ }^{19}$ http://www.uaeinteract.com/news/default3.asp?ID=361

${ }^{20} \mathrm{https}$ ://www.gcaa.ae/images/datafiles/StrategicPlan/GCAA\%20STRATEGIC\%20PLAN\%202011-2013-English.pdf

${ }^{21}$ https://infrastructure.gov.au/aviation/atmpolicy/files/ATM_Policy_Directions_Paper.pdf 
subsequent groups ${ }^{22}$ :

- UAE General Civil Aviation Authority

- Sharjah Department of Civil Aviation

- Dubai Civil Aviation Authority

- Fujairah Department of Civil Aviation

- Ras Al Khaimah Department of Civil Aviation

- International Air Transport Association (IATA)

- Dubai Air Navigation Services (DANS)

- Abu Dhabi Department of Transport

- Abu Dhabi Airports

- Dubai Airports

- Sharjah Airport Authority

- Ras Al Khaimah Airport LLC

- Dubai Airwing

- Emirates Airline

- Etihad Airways

- Flydubai

- Air Arabia Airlines

- Presidential Flight

- Global Aerospace Logistics (GAL)

- National Centre for Meteorology and Seismology

- Serco

- UAE Military

\section{The Uae Atm Strategic Plan 2015 - 2030}

The UAE ATM Strategic Plan 2015 - 2030 has been produced in association with the ATM. The UAE ATM Strategic Plan stretches out to 2030, with a 3 year scheming cycle. Consequently, the UAE ATM Strategic Plan and Schedules will be evaluated and redesigned once in a three year period, in order to guarantee that policy making is based on accurate demand and capability forecast. ${ }^{23}$

\section{UAE National Airspace Advisory Committee (Nasac)}

The GCAA has formulated the UAE National Airspace Advisory Committee (NASAC) ${ }^{24}$ with specific significance on guaranteeing safe, secure and proficient UAE Airspace organization and administration for all national, provincial and global levels in accordance with ICAO's Global ATM Operational Concept. ${ }^{25}$ The primary objective of the NASAC is, to provide a high quality service to airspace users and air navigation service providers and fostering mutual

\footnotetext{
${ }^{22}$ GM 04 UAE ATM Strategic Plan Version 1.0 issue 2014

${ }^{23}$ ibid

${ }^{24}$ https://www.gcaa.gov.ae/en/szc/pages/nasac.aspx

${ }^{25}$ http://www.icao.int/Meetings/anconf12/Document\%20Archive/9854_cons_en[1].pdf 
airspace management process with all proponents. ${ }^{26}$

\section{UAE National Air Navigation Performance Framework}

The UAE National Air Navigation Performance Framework was formulated by GCAA, in accordance with the MID Region Air Navigation Strategy ${ }^{27}$, which includes prioritization of the Aviation System Block Upgrade (ASBU) ${ }^{28}$ Block Modules. The MID Region Air Navigation Strategy also identified the KPI's, Targets and Action Plans that should be reflected in the UAE National Air Navigation Performance Framework.

\section{UAE Airspace Optimization Program 2030}

For safe and endurable civil aviation sector in the region, the UAE ATM Community developed certain action plans that to ensure the optimization of airspace:

- $\quad$ Aligned with the certain prioritized ASBU Modules, as per the ICAO MID Region Air Navigation Strategy;

- In consistence with the intentions of the UAE Airspace Policy;

- In consistence with the UAE PBN Implementation plan ${ }^{29}$; aligned with the UAE Airspace Optimization Program; and

- $\quad$ Aligned with the counsel and proposals of the NASAC.

The execution of UAE action plans will be as per the GCAA administrative procedures, with due respect to the direction gave in the suitable Regulations, Guidance Materials, and Advisory Publications. ${ }^{30}$

\section{Civil/Military Co Operation Strategy}

The UAE Civil/Military coordination plan is intended to encourage the prerequisites of the UAE Airspace with the implementation of the ICAO ASBU modules. An initial airspace design for the incorporation of military and civil flights in a joint effort with UAE military, an underlying airspace outline working in the region of Dubai airports, adaptable utilization of military airspace and new technique for military traffic was executed in May 2015 by GCAA. ${ }^{31}$ This coordination strategy brings the benefits to airspace management and air traffic management system operations of the region.

\section{CNS Strategy}

Communication, Navigation and Surveillance systems and capacities utilized in the region are covered under the CNS Strategy of the UAE. The UAE has pegged Airbus ProSky to build up a conceptual plan for the UAE in transit airspace. In the 2012-2013 airspace study, Airbus ProSky acknowledged air traffic management, airspace and communication, navigation and surveillance (CNS) challenges resulting in 53 recommendations for development. ${ }^{32}$.

\footnotetext{
${ }^{26}$ https://www.gcaa.gov.ae/en/szc/pages/nasac.aspx

${ }^{27}$ http://www.icao.int/safety/DashboardsDocumentation/MID\%20Region\%20Safety\%20and\%20AN\%20Strategy\%20(MID).pdf

${ }^{28}$ https://www.iata.org/events/Documents/asbu-panel.pdf

${ }^{29} \mathrm{http}: / /$ www.icao.int/RO_MID/Documents/2016/PBN\%20SG2/13.PBN\%20Implementation\%20-\%20UAE.pdf

${ }^{30}$ http://www.dans.gov.ae/How-we-Innovate/UAE-Airspace-Restructuring-Project

${ }^{31}$ ibid

${ }^{32}$ http://www.airbus.com/presscentre/pressreleases/press-release-detail/detail/airbus-prosky-completes-airspace-and-air-trafficmanagement-analysis-for-the-united-arab-emirates/ 


\section{Navigation}

GCAA have tagged definite operational objectives concerned with the navigation, in accordance with the UAE PBN Implementation Plan. Until 2030, the UAE navigation will be based upon GNSS, Inertial and the ILS route frameworks. This approach is predictable with ICAO MID Region Air Navigation Strategy. ${ }^{33}$

\section{Aerodromes (Atm) Strategy}

To bolster the general UAE ATM Strategic Plan, the Aerodrome strategy applies to all civil and military airports of UAE. This technique will permit the enhanced information stream on arriving flights to improve movement on the ground. This strategy upgrades the interface between airside terminal operations and ATM which assesses air terminal operations in route planning. The methodology will permit the aerodromes to consolidate mutual decision making, pre strategic and strategic stages to deal with the demand capacity adjust, enhance consistency of operations, 4-D trajectory control and streamlining of traffic sequencing. ${ }^{34}$

\section{AIM Strategy}

The GCAA initiates the Aeronautical Information Management Strategy to achieve a uniform and efficient aeronautical information management structure, based on system wide information management, to support all phases of flight. This strategy offers superior data service and total flexibility for users via the user applications concept. This will be achieved by the UAE AIS Database. ${ }^{35}$

\section{Consultative Committees}

The GCAA utilizes Consultative/Advisory Committees to address the aviation industry of the region to communicate and consult various strategies and objectives. These Committees are non-executive yet are charged, by the Director General, with leading an exchange with the specific segment of the aviation industry for every 3 months period. The Committees all have Terms of Reference and Minutes of every meeting recorded on the site and can be accessed by relevant committee members. The various consultative committees under GCAA are as follows ${ }^{36}$.

\section{Measrm : The Middle East Aviation Safety Roadmap}

The UAE GCAA is introducing the Middle East Aviation Safety Roadmap group which unites senior aviation officials from region, territorial, globally and various airlines, to concentrate basically on the new aviation safety plan of action under the as of late presented ICAO Global Aviation Safety Road Map and the International Safety Strategy Group, (ISSG). Representation from ICAO, IATA, Airbus, Boeing, ACI, CANSO, IFALPA, FAA and the FSF comprises this group. The purpose of MAESRM is to offer a an advantageous approach to associate with individual from the Top Level Safety Team (TLST) that have same interests and thoughts and discourse about current wellbeing issues and share documents, planning of events, arrangement of meetings. ${ }^{37}$

The Government anticipates that the GCAA will keep on reforming the UAE's airspace and draw towards nearer arrangement with the ICAO framework, and appropriation of demonstrated worldwide best practice with the aim of adding

\footnotetext{
${ }^{33}$ GM 04 UAE ATM Strategic Plan Version 1.0 issue 2014

${ }^{34}$ ibid

${ }^{35}$ ibid

${ }^{36}$ https://www.gcaa.gov.ae/en/ConsultCommittees/Pages/default.aspx

${ }^{37}$ https://www.gcaa.gov.ae/en/measrm/
} 
to the financial prosperity of the UAE. The Government has additionally recognized four particular airspace strategies in connection to the organization and utilization of UAE-controlled airspace, which are as per the following ${ }^{38}$

- Effective participation and coordinated effort between the ATM Community Members to accomplish concurred desires in the Key Performance Areas (KPAs)

- Support for ICAO's Global Air Traffic Management (ATM) Operational Concept and Global Air Navigation Plan (GANP)

- The appropriation of the ICAO Aviation System Block Upgrade (ASBU) program; and

- $\quad$ Enhanced ATM administrations for UAE aerodromes served via Air Services, as dictated by GCAA.

\section{Legalization of Drone Activities}

In the UAE, the General Civil Aviation Authority (GCAA) currently regulates the operation of drones or Unmanned Aircraft Systems (UAS). The GCAA recognizes that the UAS/ drone industry is diverse, innovative and international and that it has an enormous potential for growth with the associated possibility to create jobs. ${ }^{39}$ In 2014 , His Highness Sheikh Mohammed bin Rashid Al Maktoum, Prime Minister and Vice President of the United Arab Emirates and Ruler of Dubai, launched the Drones for Good award to encourage their use to improve people's lives. The award has served as a platform to introduce innovative ways of using drones. ${ }^{40}$ According to article 69 of the law, a term of imprisonment not exceeds one year and a fine not exceeding AED 50,000, or either penalty, shall be imposed to violators. ${ }^{41}$ As per the law, the first step for any new UAS/drone user is to register the drone under GCAA.

\section{Aviation Security Conferences}

GCAA held many successful conferences and conventions in the area of safety and security. One of the prominent conferences was Aviation Security Conference, held in June 2010 and resulted in Joint Abu Dhabi Declaration. The GCAA successfully conducted World Aviation Safety Summit's $4^{\text {th }}$ Edition till 2016 and the $5^{\text {th }}$ edition will be on $11^{\text {th }} \& 12^{\text {th }}$ of April 2017 to discuss about basic security measures to effectively deal with the procedures, dangers, threats and disasters confronting flight safety experts around the world. ${ }^{42}$ The 26th AVSEC World conference will be conducting in Abu Dhabi, UAE representing the full spectrum of the aviation industry experts to Figure out the recent IATA aviation security initiatives $^{43}$

\section{MILESTONE OF SPACE ACTIVITY IN UAE}

In 2015, the global space economy totaled $\$ 323$ billion worldwide according to the Space Foundation, Space Report2016. ${ }^{44}$ Over a period of time UAE has successfully diversified its economy away from dependence on oil and gas production and exports towards trade, services and industry. Major contribution in infrastructure, transport and logistics has empowered this auxiliary move in the UAE's economy to compete with the global market and being a commercial and

\footnotetext{
${ }^{38}$ ibid

${ }^{39}$ Game of Drones Issue 1 AJWAA Nov 2014; https://www.gcaa.gov.ae/en/Departments/SIA/Pages/ajwaa.aspx

40 "Drones for God" https://dronesforgood.ae/award

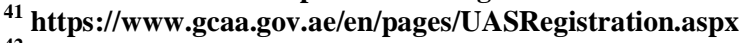

${ }^{42}$ http://worldaviationsafety.com/

${ }^{43}$ http://www.iata.org/events/avsec/Pages/index.aspx

${ }^{44}$ https://www.spacefoundation.org/media/press-releases/space-foundation-report-reveals-global-space-economy323-billion-2015
} 
tourism hub in the Middle East. ${ }^{45} \mathrm{UAE}$ needs to invest into the new frontier of space, commercial space transportation and the commercial space economy in order to remain internationally competitive and relevant.UAE is positioning itself to become a world class hub in the space industry by 2021.UAE's initial moves towards space through satellite innovation and working with associations: like National Aeronautics and Space Agency (NASA) and the European Space Agency (EASA) to prepare the young budding technocrats and researchers, and additionally using this interest in building up the nation in the coming years to be a space leaders. ${ }^{46}$

Table 2

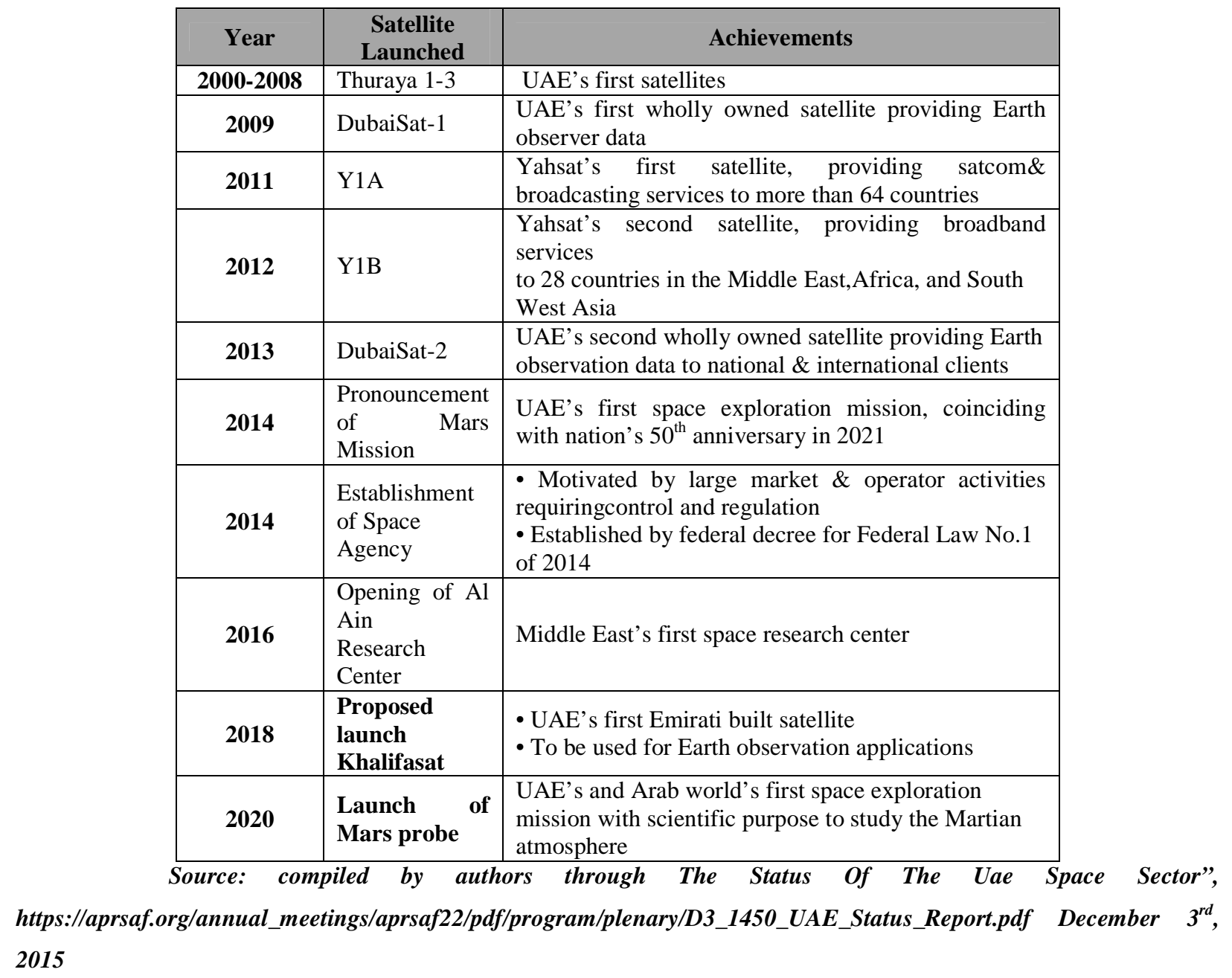

The United Arab Emirates' journey of space and satellite sector coincides very closely with the early beginnings of the UAE as a nation in $1971^{47}$ by taking membership of International Telecommunications Union, a specialized agency of the United Nations responsible for communication technologies. ${ }^{48}$ Firstly, $\mathrm{n} 2000$, the UAE agreed to the foremost

\footnotetext{
45 file:///C:/Users/gchandra/Downloads/UAE-Space-port-GB-April-2015\% 20(1).pdf

${ }^{46}$ http://www.space.gov.ae/our-initiatives

${ }^{47}$ Darcy Beamer-Downie,Nick Humphrey, "Space law and doing business in the UAE - is it realistic or out of this world?" http://www.clydeco.com/insight/article/space-law-and-doing-business-in-the-uae-is-it-realistic-or-out-of-this-world May 26th 2015 48 International Telecommunications Union [http://www.itu.int/en/Pages/default.aspx].
} 
international space conventions, when it ratified the Outer Space Treaty. ${ }^{49}$

After the Space Liability Convention ${ }^{50}$ and the Registration Convention ${ }^{51}$, the UAE turned into the enrollment nation for the satellite Thuraya 1, which propelled into space on 21 October 2000. At present, the UAE has four satellites circling Earth: Dubai Sat 1 (propelled in 2009), Yahsat 1 (propelled in 2011), Yahsat 2 (propelled in 2012) In 2014, the UAE built up a government office committed to space, the UAE Space Agency ${ }^{52}$

The UAE Space Agency supports the advancement and utilization of space science and innovation to add to the enhancement of the UAE's economy through the business space industry. The four strategic objectives set by the UAE Space Agency to be the pioneer in space sector are as follows ${ }^{53}$ :

- To organise and develop the space sector ensuring that it meets international standards and serves national interests.

- To promote and support the efforts of scientific research and innovation.

- $\quad$ To attract and prepare national cadres to become pioneers in the field of space science.

- Focused on ensuring that all the Agency's services are in accordance with worldwide quality, efficiency and transparency standards.

The UAE Space Agency holds a dual mandate as both a regulator of the space industry operating in the UAE and to organize, regulate and support the commercial space industry operating, or wishing to operate, in the UAE. The space sector, by all accounts UAE aspire to be a world class center. To underline the fact, the UAE has made initiatives, like Aabar Investments PJS, an Abu Dhabi private joint stock company, partnered with Virgin Group ${ }^{54}$

\section{GOVERNMENT INITIATIVE FOR SPACE ACTIVITIES}

UAE's space sector and the Agency is focused on developing a number of initiatives and supporting programmes that contribute to its strategic goals, which benefit the space sector and develop its human resources. Some of these initiatives include,

\section{Emiratization Training Plan}

The UAE's space division training program concentrates on profiting from local space advancements, helping local researchers and architects to concentrate on learning exchange.

\section{Little Engineer}

The UAE Space Agency and Airbus united to reveal a progression of Airbus Little Engineer Space workshops. The workshops tested students in the vicinity of 15 and 17 years of age to complete a reenactment of a dispatch mission to space. The Airbus Little Engineer Space workshop concentrated on acquainting students with the universe of space

\footnotetext{
${ }^{49}$ Treaty on Principles Governing the Activities of States in the Exploration and Use of Outer Space, including the Moon and Other Celestial Bodies ("Outer Space Treaty").

${ }^{50}$ Convention on International Liability for Damage Caused by Space Objects ("Space Liability Convention")

${ }^{51}$ Convention on Registration of Objects Launched into Outer Space ("Registration Convention").

52 UAE Federal Decree No.: 1 of 2014 on the Establishment of the United Arab Emirates Space Agency.

${ }^{53}$ Strategic Objectives United Arab Emirates Space Agency.

${ }^{54}$ RahmanFareed, “Aabar investment in Virgin Galactic at $\$ 380 \mathrm{~m}$ ”, http://gulfnews.com/business/aviation/aabar-investment-invirgin-galactic-at-380m-1.1691043, March $15^{\text {th }} 2016$ 
investigation and improving their comprehension of both the advantages and uses of space innovation. Through the span of four hours, understudies collected and launched a rocket, set up a base and built up interchanges. This helped students, hone delicate abilities including cooperation, correspondence, basic considering, open talking and inventiveness.

\section{Planet Mars Competition}

This competition opens up to all nationalities residing in UAE, without any age bar to exhibit imaginative outlines for virtual homes to suit the future populace of planet Mars. The plans submitted for the opposition ought to consider a home with a limit with regards to two individuals with a zone of around 500 square meters or more, and ought to give pragmatic and satisfactory living conditions for the inhabitants, for example, the capacity to work and lead explore inside uncommon units, and complete different recreational exercises. These homes ought to be assembled utilizing materials accessible on planet Mars, or for instance, through reusing the shuttle that moved the space explorers there.

\section{Space Rocket Competition}

The UAE Space Agency propelled the Space Rocket competition at the Dubai Airshow 2015. Students were made a request to color a spacecraft on a background of their picking, and present their work to a judging board, which chose the main 44 outlines from around 250 schools.

\section{Research Development}

The Agency plans to raise awareness to light and offer help to the space area, creating STEM training, higher graduates and skilled experts to work in the space division, who will lead it through quality administrations with the most abnormal amounts of straight forwardness

\section{Scientific Research}

The UAE Space Agency in collaboration with the Ministry of Presidential Affairs and the Telecommunications Regulatory Authority, represented by the ICT Fund is working on sending students on grants to proceed with their Bachelor and Masters considers in space sciences and other related fields. The Agency is likewise dealing with giving monetary support to a few neighborhood colleges under studies, who are keen on contemplating space sciences and other related subjects and fields.

\section{Space Research Centre}

The UAE Space Agency is engaged in foundation of its first Space Research Center in the Middle East. The Center, which will cost almost AED 100 million more than five years, is the consequence of a key association between the UAE Space Agency, UAE University and the Telecommunications Regulatory Authority defined with ICT Fund. This initive will be incubation centre for space research and advancement, to help researchers and higher education institutes intrigued to have the capacity of adding to space research.

\section{UAE Observsssatory}

The UAE Space Agency is working with important experts on the UAE Observatory extend, which will improve space research and development in the country. The observatory is wanted to be based on the pinnacle of Jais Mountain in Ras Al Khaimah around 1850 meters above ocean level and at a cost of 30 million dirhams. Once finished, the observatory will be the biggest of its kind in the Arab world. MBRSC launched "DubaiSat-1" in 2009, the first remote sensing satellite. 
Second satellite "DubaiSat-2" was launched in 2013; third satellite "KhalifaSat" is underway.

\section{Hope Probe; Uae First Step to Mars Mission}

Hope is a probe developed to study the red planet's climate, and the UAE's young space program has uncovered enormous aspirations to place it in circle around Mars by $2021 .{ }^{55}$ The Arab world's first mission to Mars will start the 62 million kilometer voyage to the red planet from an island in south Japan. Hope is set to dispatch from the Tanegashima Space Center in July 2020 using a Mitsubishi Heavy Industries rocket carrier. ${ }^{56}$

According to Mr.Al Shaibani, "The Hope probe will not only send us images and data on the Martian atmosphere, it will also carry a message of hope to young Arab generations and will open the doors to a new era of scientific and technological invention and discovery," ${ }^{, 57}$. More importantly, this mission represents a huge technological leap for our society, playing a key role in fostering greater research, development and innovation. The Emirates Mars mission is the cornerstone of the Mohammed bin Rashid Space Centre's mission to build an ambitious program for space exploration that falls in line with the objectives of the UAE Vision 2021 for economic competitiveness ${ }^{58}$

\section{SPACE POLICY AND PARTNERSHIP}

\section{Local Partnership}

UAE space industry partner such as Thuraya, Al Yah Sat and Emirates Institute for Advanced Sciences and Technology (EIAST), who have been successfully operating for many years, are ranked among major international players within the industry. American University of Ras al Khaima (AURAK) signed MOU with UAE Space agency

\section{International Partnership}

Space Agency has successfully established relationships with several global space industry organizations, and agencies that had a common vision for space exploration. This includes, signing MoU's with NASA and the national space agencies of France ${ }^{59}$, Russia ${ }^{60}$, Japan, China, and the United Kingdom, among other. ${ }^{61}$

According to HE Dr. Al Ahbabi ${ }^{62}$, "The United Arab Emirates and the United States of America are strategic allies and have deep economic ties. This partnership offers many opportunities for both countries, particularly in the field of space, and we invite the American space industry to come visit us in the UAE and learn about our own space sector, and explore ways both countries can collaborate,"63

Uae Space Policy and Law

The UAE opted a strategy to develop its space sector to had firm the collaboration between Government and

\footnotetext{
${ }^{55}$ Kramer Miriam, “The UAE's pArobe, Hope, could fly to Mars by 2020”, http://mashable.com/2015/05/08/hopemars-mission-uae/\#TE9CYlkYtkqJ,MAY $8^{\text {th }}, 2015$

${ }^{56}$ Moukhallati Dana, http://www.thenational.ae/uae/science/conquering-space-is-about-solving-problems-dubaipupils-told,January $24^{\text {th }} 2017$

${ }^{57}$ H.E Yosouf Hamad Al Shaibani, Director General, Mohammed bin Rashid Space Centre (MBRSC)

58 ibid

${ }^{59}$ Binsal Abdul Kader, “UAE likely to join elite club of space powers”, http://gulfnews.com/news/uae/government/uae-likely-to-join-elite-club-of-space-powers-1.1489177,April $9^{\text {th }} 2015$

${ }^{60}$ https://sputniknews.com/science/201512061031329709-russia-uae-space/

${ }^{61} \mathrm{http}: / / \mathrm{www}$.space.gov.ae/uae-space-agency-celebrates-second-anniversary

${ }^{62}$ Chairman of the UAE Space Agency board and the Agency's Director General

${ }^{63} \mathrm{http}$ ://www.space.gov.ae/uae-space-agency-seeks-strategic-cooperation-united-states-space-sector
} 
private sector to established partnerships to adhere global laws and settlements; conducting space missions that will increment logical learning; developing advances and national capacities and driving development; encouraging a stable and sustainable space environment that supports commercial and government space activities; and Follow-up measures to ensure the space policy's successful implementation. The policy aims to build a strong and sustainable space sector in the UAE that supports and protects national interests and related vital industries. ${ }^{64}$

The beliefs of the policy is professed to support national security space activities, but it's not clarify how it's going to supports national security interests because it is unusual its National Space Policy would not have included the defense sector, This is strange, as the UAE is set to receive two Falcon Eye photo-reconnaissance satellites, which will give the UAE significant remote sensing and intelligence-gathering capabilities. ${ }^{65}$ The UAE is a signatory of the UN's Convention on the Registration of Objects Launched into Outer Space, however has not yet joined to the Space Protocol and the Cape Town Convention on International Interests in Mobile Equipment, Signing these international protocols and conventions would be a foundation for the UAE to become a space economy financier.

UAE space law addressed both the civil space sector and creates a private interest in commercial space activities, which would fit together with the UAE's goal of becoming a regional hub of space activities. ${ }^{66}$ The UAE would incorporate "space assets" in its domestic space law as a support for the law's acknowledgment as standard international law, which would permit the UAE to position itself as a legitimate and financial epicenter for encouraging the securing of "space assets" and to go about as a monetary trade for their deal. ${ }^{67}$

\section{CONCLUSIONS}

UAE government has taken lot of initiative and supporting and fostering the strategic plan. The Government plans to adopt changes to its air and space laws, and undoubtedly a righteous step for the growth of air and space market, signing various MoU liberalizing air transport regimes, Indeed there are certain aspects of aviation law dealt case to case basis.

As the UAE continues to enhance and develop its regulatory framework to attract foreign investment and the brightest and best human capital, there will be collateral benefits to the growth and evolution of the UAE space industry.

With the goal of setting UAE's space sector policy and explored ways to transform the country into a regional space hub, UAE has to revisit its National Space Policy to include the national security to space sector and ensure that the space law will covered both human space exploration and commercial activities, UAE space industry has to developed local and international partnerships, and raise awareness locally on the importance of space.

UAE Air and Space strategies policies, public private partnership serves as an impetus for financial advancement and enhancement, creating work space and empowering researchers and designers to be the pioneers of the industry, as well as other endeavors in the peaceful exploration of outer space.

\section{REFERENCES}

1. "Mohammed bin Rashid Space Centre showcases “ http://www.mediaoffice.ae/en/media-center/news/5/11/2016/mbrsc.aspx

\footnotetext{
64 "Space Agency announces details of space policy", http://gulfnews.com/news/uae/government/space-agencyannounces-details-of-space-policy-1.1892752,September $7^{\text {th }} 2016$

${ }^{65}$ Christopher Stone elaborates on this concern in his blog Real Space Strategy: https://realspacestrategy.wordpress.com/2015/12/29/some-thoughts-on-the-uae-china-space-mou/ ${ }^{66} \mathrm{https}: / /$ spacewatchme.com/2016/11/uae-national-space-policy-initial-assessment/ ${ }^{67}$ ibid
} 
2. Clayton Edward,Hilz Andreas, "2015 Aviation Trends”, http://www.strategyand.pwc.com/trends/2015-aviation-trends

3. Clayton Edward,Hilz Andreas, "2015 Aviation Trends”, http://www.strategyand.pwc.com/trends/2015-aviation-trends

4. Jain Shweta, “UAE aviation: A story of takeoffs and landings",http://gulfnews.com/business/aviation/uae-aviation-a-story-oftakeoffs-and-landings-1.925143, November $7^{\text {th }} 2011$

5. “UAE aviation industry sees robust growth”, http://gulftoday.ae/portal/a5d9bbal-d58f-4494-89b5-2a26bf26315a.aspx,July $20^{\text {th }} 2015$

6. https://www.gcaa.gov.ae/en/departments/airaccidentinvestigation/pages/default.aspx

7. https://www.gcaa.ae/cms_data/Files/Federal\%20Act\%20no\%2020\%20for\%201991\%20Civil\%20Aviation\%20Law\%20Eng.pdf

8. GM 04 UAE ATM Strategic Plan Version 1.0 issue 2014 (2).pdf

9. GCAA, General Civil Aviation Authorit, 2014. UAE CIVIL AVIATION DAY. AJWAA, Issue 1, 12,13.

10. Regulations Specialist, nyadav, 2015. UAE, GCAA CAR - PART VII AVIATION SECURITY REGULATIONS. CAR - PART VII AVIATION SECURITY REGULATIONS, Third Edition, October 2015, 3-1

11. https://www.gcaa.gov.ae/en/Departments/ASI/Pages/AviationSafetySecurity.aspx.

12. https://www.gcaa.gov.ae/en/ePublication/Pages/uaessp.aspx

13. https://www.gcaa.gov.ae/en/rosi/pages/details.aspx?_Lst=GCAA_Welcome:Body

14. https://www.gcaa.gov.ae/en/epublication/admin/Publication\%20History/Civil\%20Aviation\%20Advisory\%20Publication\%20( CAAP)/CAAP\%208\%20-\%20AIR\%20OPERATERS\%20CERITIFICATE\%20(AOC)\%20ISSUE\%2002\%20$\% 20 R E V \% 2000 . p d f$

15. https://www.gcaa.gov.ae/en/pages/events.aspx?EventID=10

16. http://www.icao.int/RO_MID/Documents/2014/AIDC-OLDI\%20Seminar/Presentation1OLDI\%20Experience\%20Sharing\%20-\%20UAE.pdf

17. https://www.gcaa.gov.ae/en/lists/gcaa\%20communication\%20channels\%20survey/newform.aspx?Source=/en/Pages/sThankY ou.aspx

18. https://www.mcgill.ca/iasl/files/iasl/Session_5_Karam.pdf

19. http://www.uaeinteract.com/news/default3.asp? ID $=361$

20. https://www.gcaa.ae/images/datafiles/StrategicPlan/GCAA\%20STRATEGIC\%20PLAN\%202011-2013-English.pdf

21. https://infrastructure.gov.au/aviation/atmpolicy/files/ATM_Policy_Directions_Paper.pdf

22. GM 04 UAE ATM Strategic Plan Version 1.0 issue 2014

23. ibid

24. https://www.gcaa.gov.aelen/szc/pages/nasac.aspx

25. http://www.icao.int/Meetings/anconf12/Document\%20Archive/9854_cons_en[1].pdf

26. https://www.gcaa.gov.ae/en/szc/pages/nasac.aspx

27. http://www.icao.int/safety/DashboardsDocumentation/MID\%20Region\%20Safety\%20and\%20AN\%20Strategy\%20(MID).pdf 
28. https://www.iata.org/events/Documents/asbu-panel.pdf

29. http://www.icao.int/RO_MID/Documents/2016/PBN\%20SG2/13.PBN\%20Implementation\%20-\%20UAE.pdf

30. http://www.dans.gov.ae/How-we-Innovate/UAE-Airspace-Restructuring-Project

31. ibid

32. http://www.airbus.com/presscentre/pressreleases/press-release-detail/detail/airbus-prosky-completes-airspace-and-air-trafficmanagement-analysis-for-the-united-arab-emirates/

33. GM 04 UAE ATM Strategic Plan Version 1.0 issue 2014

34. ibid

35. ibid

36. https://www.gcaa.gov.ae/en/ConsultCommittees/Pages/default.aspx

37. https://www.gcaa.gov.ae/en/measrm/

38. ibid

39. Game of Drones Issue 1 AJWAA Nov 2014; https://www.gcaa.gov.ae/en/Departments/SIA/Pages/ajwaa.aspx

40. “Drones for God" https://dronesforgood.ae/award

41. https://www.gcaa.gov.ae/en/pages/UASRegistration.aspx

42. http://worldaviationsafety.com/

43. http://www.iata.org/events/avsec/Pages/index.aspx

44. https://www.spacefoundation.org/media/press-releases/space-foundation-report-reveals-global-space-economy-323-billion2015

45. file:///C:/Users/gchandra/Downloads/UAE-Space-port-GB-April-2015\%20(1).pdf

46. http://www.space.gov.ae/our-initiatives

47. Darcy Beamer-Downie,Nick Humphrey, "Space law and doing business in the UAE - is it realistic or out of this world?" http://www.clydeco.com/insight/article/space-law-and-doing-business-in-the-uae-is-it-realistic-or-out-of-this-world May 26th 2015

48. International Telecommunications Union [http://www.itu.int/en/Pages/default.aspx].

49. Treaty on Principles Governing the Activities of States in the Exploration and Use of Outer Space, including the Moon and Other Celestial Bodies ("Outer Space Treaty”).

50. Convention on International Liability for Damage Caused by Space Objects ("Space Liability Convention")

51. Convention on Registration of Objects Launched into Outer Space ("Registration Convention").

52. UAE Federal Decree No.: 1 of 2014 on the Establishment of the United Arab Emirates Space Agency.

53. Strategic Objectives United Arab Emirates Space Agency.

54. RahmanFareed, “Aabar investment in Virgin Galactic at $\$ 380 m$ ”, http://gulfnews.com/business/aviation/aabar-investment-invirgin-galactic-at-380m-1.1691043, March $15^{\text {th }} 2016$ 
55. Kramer Miriam, “The UAE's pArobe, Hope, could fly to Mars by 2020”, http://mashable.com/2015/05/08/hope-marsmission-uae/\#TE9CYlkYtkqJ,MAY $8^{\text {th }}, 2015$

56. Moukhallati Dana, http://www.thenational.ae/uae/science/conquering-space-is-about-solving-problems-dubai- pupilstold,January $24^{\text {th }} 2017$

57. H.E Yosouf Hamad Al Shaibani, Director General, Mohammed bin Rashid Space Centre (MBRSC)

58. ibid

59. Binsal Abdul Kader, "UAE likely to join elite club of space powers", http://gulfnews.com/news/uae/government/uae-likely-tojoin-elite-club-of-space-powers-1.1489177,April $9^{\text {th }} 2015$

60. https://sputniknews.com/science/201512061031329709-russia-uae-space/

61. http://www.space.gov.ae/uae-space-agency-celebrates-second-anniversary

62. Chairman of the UAE Space Agency board and the Agency's Director General

63. http://www.space.gov.ae/uae-space-agency-seeks-strategic-cooperation-united-states-space-sector

64. “Space Agency announces details of space policy”, http://gulfnews.com/news/uae/government/space-agency-announcesdetails-of-space-policy-1.1892752,September $7^{\text {th }} 2016$

65. Christopher Stone elaborates on this concern in his blog Real Space Strategy: https://realspacestrategy.wordpress.com/2015/12/29/some-thoughts-on-the-uae-china-space-mou/

66. https://spacewatchme.com/2016/11/uae-national-space-policy-initial-assessment/

67. ibid 
